\title{
Breeding Hexaploid Triticale (X Triticosecale Wittmack) with High Bread Making Quality
}

\author{
${ }^{1}$ Plant Production Institute, Ukraine \\ ${ }^{2}$ Volhynia SAES of NAAS, Ukraine \\ ${ }^{3}$ Wibex laboratory, Poland \\ *Corresponding author: Shchipak GV, Plant Production Institute and Yuryev of NAAS, Kharkiv, Ukraine
}

Shchipak GV'*, Svyatchenko SI ${ }^{1}$, Shchipak VG ${ }^{2}$, Nychyporuk $0^{2}{ }^{2}$,Woś $\mathrm{H}^{3}$, Brzeziński $\mathrm{W}^{3}$ and Boguslavskyi RL ${ }^{1}$

Submission: 海April 04, 2018; Published: 海 July 09, 2018

\section{Introduction}

Breeding the hexaploid triticale is directed to increase productivity, its stability, improvement of grain quality with retention of a complex of adaptive properties. In Ukraine, the triticale cultivars specialized to destination are introduced in the agrarian production differing significantly in economic valuable signs [1- 4]. Fodder triticale Amphidiploid 256, Garne, Bouquet, Shalanda which acquired spread in all agroecological zones of the country, ensure high grain yields (7.5-10.5t/ha) and green crop (4565t/ha). The cultivars of food and universal appointment Amos, Nicanor, Raritet, Plastun volynskiy, Yaroslava are characterized by good and excellent indicators of quality of a gluten, dough and bread at grain productivity of 8.5-11.5t/ha.

These cultivar groups belong to the semi-intensive type, are well adapted to a complex of adverse factors of wintering and vegetation. Nevertheless, they are prone to lodging in abnormally damp years what reduces yield capacity, especially, on a rich soil. For such conditions, a triticale cultivar with plant height of $85-100 \mathrm{~cm}$ are created [5]. During breeding the baking triticale, it should be expanded search of hybrid combinations with the minimum negative influence of rye chromosomes, and selection of posterities with complementary nature of interaction of the wheat and rye genetic systems should be carried out also among the forms with low gluten content but with high rates of elasticity and tensile properties of dough achieving balance of gluten complex at a high level.

For this purpose, since 1980 to 2017, 16.3 thousand combinations including $67.9 \%$ of intraspecific crossings are carried out. Based on the hybridization of triticale $2 n=42 \times 2 n=42$ with various growth habit, there are created and transferred to state testing 26 cultivars. In the population $\mathrm{F}_{3}\left(\mathrm{~F}_{1}\right.$ (spring triticale Kharkivskyi 41/D77)// D77-75), there was selected in 1988 the alternate line D8-192 with easy thresh and well executed grain of wheaten morphology [6]. One of the most valuable hybrid combinations $\mathrm{F}_{1}$ (Amphidiploid 547/D8-192) / spring triticale Aist Kharkivskyi) was carried out in 1989.

From it, by means of repeated selections in the contrast conditions of Forest Steppe and sharply arid Steppe, the comprehensively valuable lines were obtained which have the various on quality gluten-from weak to very strong: GDI 45-120 units, number of falling of 236-394 sec, dough elasticity $40-95 \mathrm{~mm}$, tensile strength $30-110 \mathrm{~mm}$. Stabilization of quality of a gluten complex at the high level was reached in the created cultivar by association of a respective complementary lines. The mixing effect was intensified due to the increased elasticity of dough of some lines and unique tensile ability of other lines [7].

The genetic basis of the cultivar Raritet was made by the lines with contrast indexes of dough quality: tensile strength to $86 \mathrm{~mm}$, elasticity to $79 \mathrm{~mm}$, what promoted formation of the gluten complex balanced at the high level $(\mathrm{P} / \mathrm{L}=82 / 77)$, increase of flour strength (to 222a.u.) and obtaining high-quality bread without improvers (550-600ml). Wide use of the Raritet in intraspecific crossings revealed its extraordinary combination ability including quality of gluten, dough and bread. There were open a new opportunity to increase baking properties of triticale that was limited by very strong but insufficiently gluten tensile strength of the cultivar Raritet.

For improvement of the cultivar type of bread making destination, a numerous crossing was carried out. As the most valuable combinations are recognized the options with participation of the forms with weak but viscous, excessively extensible gluten: Amphidiploid 206/Raritet, Raritet/Valentin 90 and Raritet/HAD 7 from which the lines with more elastic-strong and at the same time tensile strength gluten are selected. On their basis, new multiline cultivars of baking and universal types are created: Amos 
(it is registered since 2014), Markiyan (since 2015), Nicanor (since 2016) (Figure 1). Creation of these cultivars increased significantly quality of triticale bread: the volume increased to $650 \mathrm{ml}$ at the general baking value of 9,0 points.

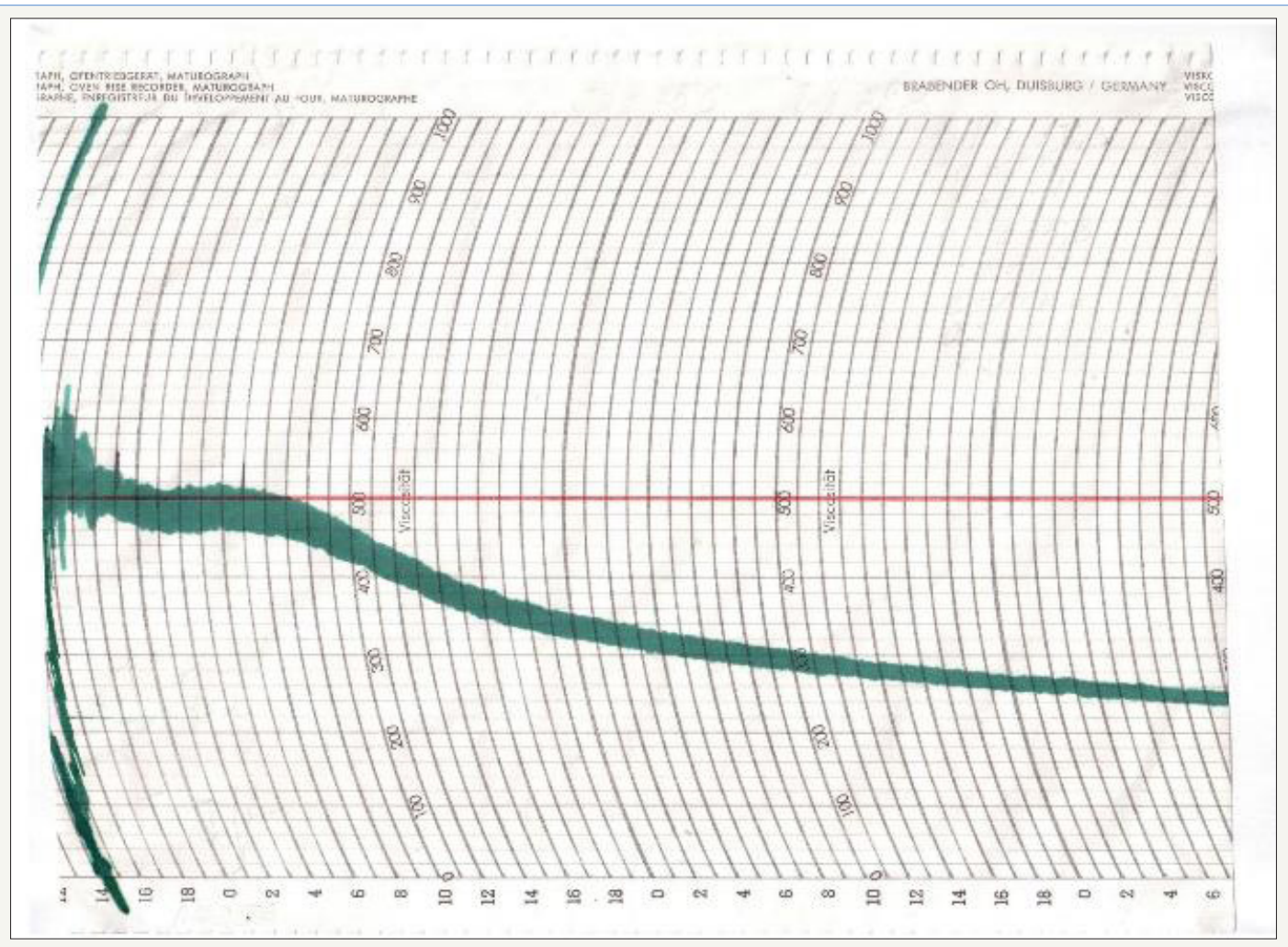

Figure 1: Farinogramm of the triticale cultivar Amfidyploid 256 (2016).

Improvement of triticale competitiveness requires combination in one cultivar of increased grain yield with short stem and high baking quality while maintaining complex resistance to unfavorable factors. A such forms were absent in the available assortment. Undersized cultivars from Poland, Romania, Slovakia, Russia possess high potential productivity but a weak gluten and are used mainly for the fodder and technical purposes. While perennial tests of the population Raritet/HAD 7 in contrast conditions, we are selected constant highly productive triticale with plant height of $40-105 \mathrm{~cm}$.

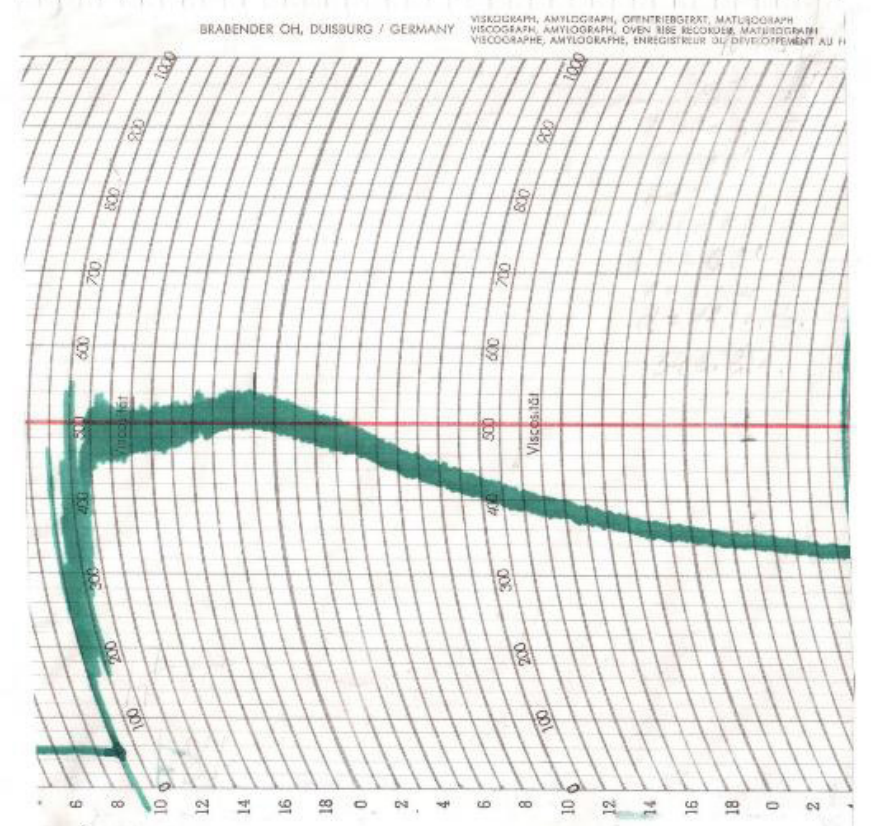

Figure 2: Farinogramm of the triticale cultivar Buket (2016). 
Obtaining of low-stem forms when crossing tall components isn't the unique phenomenon, as a genealogy of the Raritet includes forms of triticale and wheat with a short stem. The complementarity of initial genotypes by technological qualities, high rates of dough tensile strength of HAD 7 and elasticticy of a gluten complex in the Raritet increased probability of selection, at rather large sample size, the low-stem lines with the excellent baking qualities, best than in the parental forms. In the conditions of 2014-2017, the low-stem lines of triticale $(2,8$ thousand samples) allocated from a combination Raritet/HAD 7 differed by good and excellent winter hardiness (8.2-9.0 points), had 530-640 ears on $1 \mathrm{~m}^{2}$ with a plant height of $62-98 \mathrm{~cm}$ that is equal to the level of a low-stem Polish cultivar Baltiko (Figure 2).

In comparison with the Raritet, plant height is reduced by 30 $50 \%$ by shortening of all internodes, mostly due the middle $\left(\mathrm{l}_{4}\right)$ and lower $\left(\mathrm{l}_{5}, \mathrm{l}_{6}\right)$ that increased the lodging resistance to 9 points. Duration of the vegetation period of the low-stem lines corresponds to initial forms (275-278 days). The new triticale inherited mainly high resistance to smut and foliar-stem diseases. These lines passed through selections in the acute arid steppe show high resistance to heat and form well filled grain with 1000 kernel weight of 44.362.5g. In droughty conditions of 2014-2017, the grain productivity of the best low-stem cultivars Timofey, Pudik and Yelan varied from 8.82 to $10.77 \mathrm{t} /$ ha and averaged 9.94-10.36t/ha that exceeds the standard cultivars Raritet by 3.07-3.49 t/ha, Baltiko - by 1,81 - 2,23 t/ha, the wheat Podolyanka by 3.69- 4.11t/ha.

The physical grain properties of low-stem triticale are good and excellent. The test weight varied in the range of $662-804 \mathrm{~g} / \mathrm{l}$, a grain virtuosity-of $17-52 \%$, a grain hardness-of 76,4-123.0 N. The sedimentation indexes $(33-40 \mathrm{ml})$ in new lines are higher in comparison with fodder triticale Amphidiploid 256 and Pawo (27$31 \mathrm{ml}$ ). The observed variability of falling number (73-230sec), had no essential impact on quality. The low-stem triticale characterized by low grain protein content (9.8-11.9\%) what is at the level of the parental Raritet (Figure 3). Quantity of a gluten in flour of low-stem amphidiploids is various: $10.0-22.0 \%$. The Raritet had a gluten output of $16,0-19.3 \%$, the wheat-20.0-27.9\%.

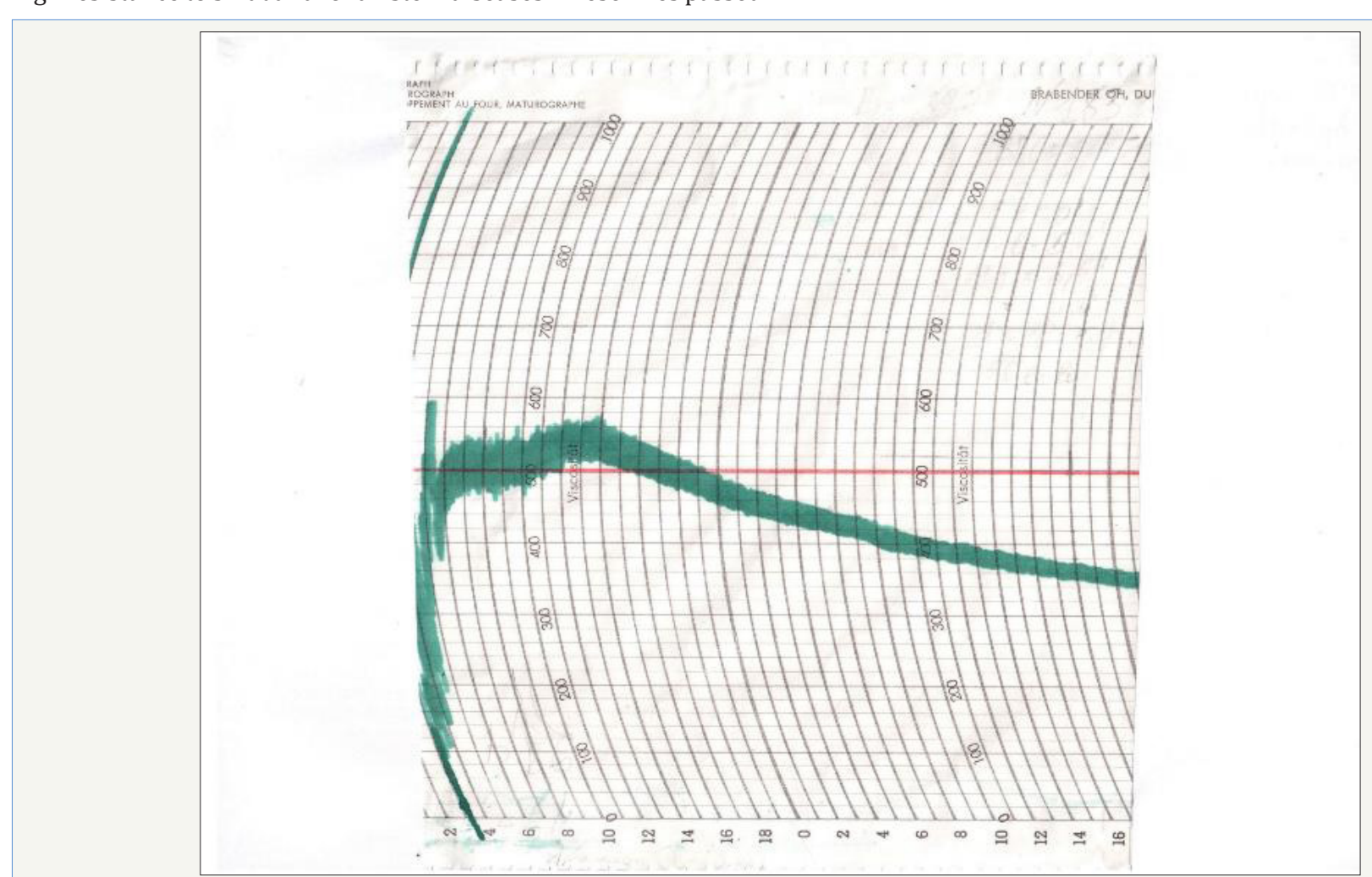

Figure 3: Farinogramm of the triticale cultivar Valentyn 90 (2016).

Table 1: Morphological and technological traits of hexaploid triticale and wheat $(2014-2017 \bar{X})$.

\begin{tabular}{|c|c|c|c|c|c|c|c|c|c|c|c|c|}
\hline Cultivar & $\begin{array}{c}\text { Plant } \\
\text { Height, } \\
\text { cm }\end{array}$ & $\begin{array}{c}\text { Yield } \\
\text { Capacity, } \\
\text { t/ha }\end{array}$ & $\begin{array}{c}\text { Protein } \\
\text { in } \\
\text { Grain, } \\
\text { \% }\end{array}$ & $\begin{array}{c}\text { Gluten } \\
\text { in Flour, } \\
\%\end{array}$ & GDI, & $\begin{array}{c}\text { Falling } \\
\text { Number, } \\
\text { units }\end{array}$ & $\begin{array}{c}\text { Elasticity } \\
\text { of Dough, } \\
\text { mm }\end{array}$ & $\begin{array}{c}\text { Tensile } \\
\text { Strength } \\
\text { of Dough, } \\
\text { mm }\end{array}$ & $\begin{array}{c}\text { Flour } \\
\text { Strength } \\
\text { u.a. }\end{array}$ & $\begin{array}{c}\text { Loaf Volume, } \\
\text { ml }\end{array}$ & $\begin{array}{c}\text { Bread Mak- } \\
\text { ing Rating, } \\
\text { point }\end{array}$ \\
\hline \multicolumn{7}{|c|}{ Triticale winter } \\
\hline $\begin{array}{c}\text { Amphidiploid } \\
\text { 256, St }\end{array}$ & 136 & 5,61 & 12.30 & 16.7 & 82 & 206 & 39 & 37 & 57 & 473 & 6.6 \\
\hline Raritet, St & 125 & 6.87 & 11.52 & 17.4 & 55 & 254 & 71 & 74 & 194 & 627 & 9.0 \\
\hline
\end{tabular}




\begin{tabular}{|c|c|c|c|c|c|c|c|c|c|c|c|}
\hline Shalanda & 138 & 7.64 & 12.27 & 14.8 & 117 & 156 & 46 & 51 & 55 & 465 & 6.5 \\
\hline Bouquet & 139 & 7.95 & 11.85 & 16.9 & 75 & 208 & 48 & 62 & 98 & 486 & 8.1 \\
\hline Nikanor & 127 & 8.02 & 11.62 & 18.5 & 55 & 195 & 69 & 78 & 180 & 590 & 8.5 \\
\hline Amos & 123 & 7.33 & 11.48 & 16.9 & 58 & 246 & 75 & 79 & 203 & 640 & 9.0 \\
\hline Timofey & 92 & 9.94 & 11.67 & 17.0 & 54 & 152 & 84 & 81 & 210 & 698 & 8.7 \\
\hline Pudik & 90 & 10.14 & 11.39 & 20.3 & 45 & 226 & 81 & 77 & 226 & 727 & 9.0 \\
\hline Yelan & 94 & 10.36 & 11.87 & 19.0 & 50 & 199 & 72 & 77 & 229 & 800 & 9.0 \\
\hline \multicolumn{12}{|c|}{ Triticale alternate } \\
\hline Yaroslava* & 98 & 3.72 & 12.80 & 22.0 & 68 & 180 & 58 & 65 & 132 & 498 & 8.3 \\
\hline Yaroslava** & 125 & 8.68 & 12.18 & 20.4 & 63 & 203 & 65 & 77 & 157 & 617 & 8.7 \\
\hline Aleksandra* & 102 & 4.10 & 12.69 & 21.8 & 65 & 178 & 84 & 62 & 156 & 600 & 8.5 \\
\hline Aleksandra** & 128 & 8.56 & 12.06 & 18.6 & 50 & 206 & 88 & 57 & 196 & 640 & 8.6 \\
\hline \multicolumn{12}{|c|}{ Triticale spring } \\
\hline Aist $\mathrm{x} .^{*}$ & 102 & 3.01 & 12.96 & 21.5 & 70 & 231 & 57 & 64 & 124 & 417 & 6.6 \\
\hline Aist x.** & 135 & 6.14 & 12.34 & 19.0 & 70 & 207 & 71 & 50 & 131 & 440 & 7.1 \\
\hline Hlibodar* & 112 & 3.32 & 12.04 & 23.4 & 70 & 197 & 57 & 66 & 129 & 426 & 7.4 \\
\hline Darhliba* & 116 & 3.51 & 12.02 & 17.0 & 63 & 183 & 56 & 55 & 109 & 490 & 7.6 \\
\hline \multicolumn{12}{|c|}{ Wheat winter } \\
\hline Podolyanka, st & 102 & 6.25 & 12.44 & 27.0 & 63 & 263 & 72 & 69 & 207 & 657 & 8.8 \\
\hline HIP05 & & 0.43 & & & & & & & & & \\
\hline
\end{tabular}

* - spring crops

** - autumn crops

Table 2: Physical properties of dough and bread volume of triticale and wheat $(2014-2017, \bar{X})$.

\begin{tabular}{|c|c|c|c|c|c|c|c|c|c|c|}
\hline \multirow[b]{2}{*}{ Cultivar } & \multirow[b]{2}{*}{ Country } & \multirow{2}{*}{$\begin{array}{l}\text { Flour } \\
\text { Strength, } \\
\text { a.u. }\end{array}$} & \multirow{2}{*}{$\begin{array}{l}\text { Water Ab- } \\
\text { sorption, } \\
\%\end{array}$} & \multicolumn{5}{|c|}{ Dough } & \multirow{2}{*}{$\begin{array}{c}\text { General } \\
\text { Valorimetric } \\
\text { Value, u.v. }\end{array}$} & \multirow{2}{*}{$\begin{array}{c}\text { Loaf } \\
\text { Volume, } \\
\text { ml }\end{array}$} \\
\hline & & & & $\begin{array}{c}\text { Time of } \\
\text { Rormation, } \\
\text { min }\end{array}$ & $\begin{array}{l}\text { Resilience, } \\
\text { min }\end{array}$ & $\begin{array}{c}\text { Resistance, } \\
\text { min }\end{array}$ & $\begin{array}{l}\text { Stability, } \\
\text { min }\end{array}$ & $\begin{array}{l}\text { Softening, } \\
\text { u.f. }\end{array}$ & & \\
\hline $\begin{array}{l}\text { Amphidiploid } \\
\text { 256, St }\end{array}$ & Ukraine & 57 & 56,0 & 1,95 & 2,29 & 4,24 & 4,03 & 156 & 48 & 473 \\
\hline Raritet, St & Ukraine & 194 & 55,1 & 2,65 & 6,46 & 9,17 & 9,10 & 87 & 74 & 627 \\
\hline Markiyan & Ukraine & 180 & 57,0 & 2,45 & 4,23 & 6,44 & 7,73 & 99 & 71 & 610 \\
\hline Nikanor & Ukraine & 180 & 57,6 & 2,98 & 3,50 & 5,98 & 7,15 & 105 & 69 & 590 \\
\hline Amos & Ukraine & 203 & 54,1 & 2,50 & 6,50 & 9,00 & 9,15 & 82 & 78 & 640 \\
\hline Yaroslava & Ukraine & 157 & 59,0 & 2,50 & 4,00 & 5,62 & 6,45 & 140 & 61 & 617 \\
\hline Timofey & Ukraine & 210 & 53,4 & 2,85 & 10,75 & 13,60 & 15,15 & 81 & 84 & 698 \\
\hline Pudik & Ukraine & 226 & 55,5 & 3,20 & 12,50 & 15,70 & 17,20 & 62 & 90 & 727 \\
\hline Yelan & Ukraine & 229 & 54,8 & 2,90 & 10,50 & 13,40 & 13,85 & 75 & 86 & 800 \\
\hline Valentin 90 & Russia & 140 & 57,8 & 1,99 & 3,00 & 5,45 & 4,66 & 140 & 57 & 490 \\
\hline Hermes & Russia & 59 & 48,0 & 1,80 & 0,50 & 2,30 & 3,00 & 140 & 34 & 420 \\
\hline Kapriz & Russia & 93 & 58,3 & 2,33 & 2,75 & 5,08 & 5,00 & 169 & 55 & 465 \\
\hline Kroha & Russia & 20 & 49,8 & 2,00 & 1,00 & 3,00 & 4,00 & 210 & 25 & 390 \\
\hline Lamberto & Poland & 102 & 57,9 & 1,30 & 3,00 & 4,30 & 5,00 & 220 & 49 & 420 \\
\hline Pawo & Poland & 65 & 55,6 & 2,10 & 2,03 & 4,27 & 3,47 & 180 & 48 & 390 \\
\hline Domital & Poland & 39 & 49,8 & 2,20 & 2,00 & 4,20 & 4,80 & 160 & 34 & 430 \\
\hline Baltiko & Poland & 39 & 54,0 & 1,80 & 1,50 & 3,30 & 5,40 & 170 & 32 & 360 \\
\hline
\end{tabular}




\begin{tabular}{|c|c|c|c|c|c|c|c|c|c|c|}
\hline Titan & Romania & 26 & 49,2 & 1,90 & 1,30 & 3,20 & 3,20 & 190 & 39 & 390 \\
\hline Gorun & Romania & 52 & 50,0 & 1,50 & 0,50 & 2,00 & 3,70 & 185 & 30 & 420 \\
\hline Stil & Romania & 39 & 53,0 & 2,00 & 1,20 & 3,20 & 4,00 & 200 & 39 & 400 \\
\hline Kandur & Slovakia & 26 & 51,6 & 1,90 & 1,10 & 2,90 & 4,00 & 170 & 29 & 390 \\
\hline $\begin{array}{c}\text { Amphidiploid } \\
\text { 206 }\end{array}$ & USSR & 103 & 55,1 & 2,10 & 0,50 & 2,60 & 1,50 & 220 & 34 & 467 \\
\hline $\begin{array}{c}\text { Podolyanka, } \\
\text { wheat soft }\end{array}$ & Ukraine & 207 & 59,7 & 2,82 & 10,20 & 13,07 & 15,47 & 73 & 85 & 657 \\
\hline
\end{tabular}

The low-stem triticale form exclusively elastic and strong gluten: the GDI index varied from 30 to 55 u., many lines surpassed both bread wheat (63u.) and the best cultivar on this trait Raritet (55u.). The cultivar types of triticale differ significantly on flour strength. In winter triticale of fodder type it makes 55-98u.a., spring triticale-109-131u.a. In comparison with spring amphidiploids, triticale of alternate growth habit Yaroslava and Alesandra formed stronger flour especially at autumn sowing (157-196u.a.). Steadily high value of flour strength was ascertained first in the Raritet. On average in 10 years (2001-2011), this index reached in this cultivar 193 u.a., at the spring cultivar Aist-121u.a., spring wheat Kharkivska 26-200u.a., winter wheat Odesskaya 267-319u.a. [8]. The similar ratio of flour strength in various cultivars was observed also in 2014-2017 (Table 1 \& 2).

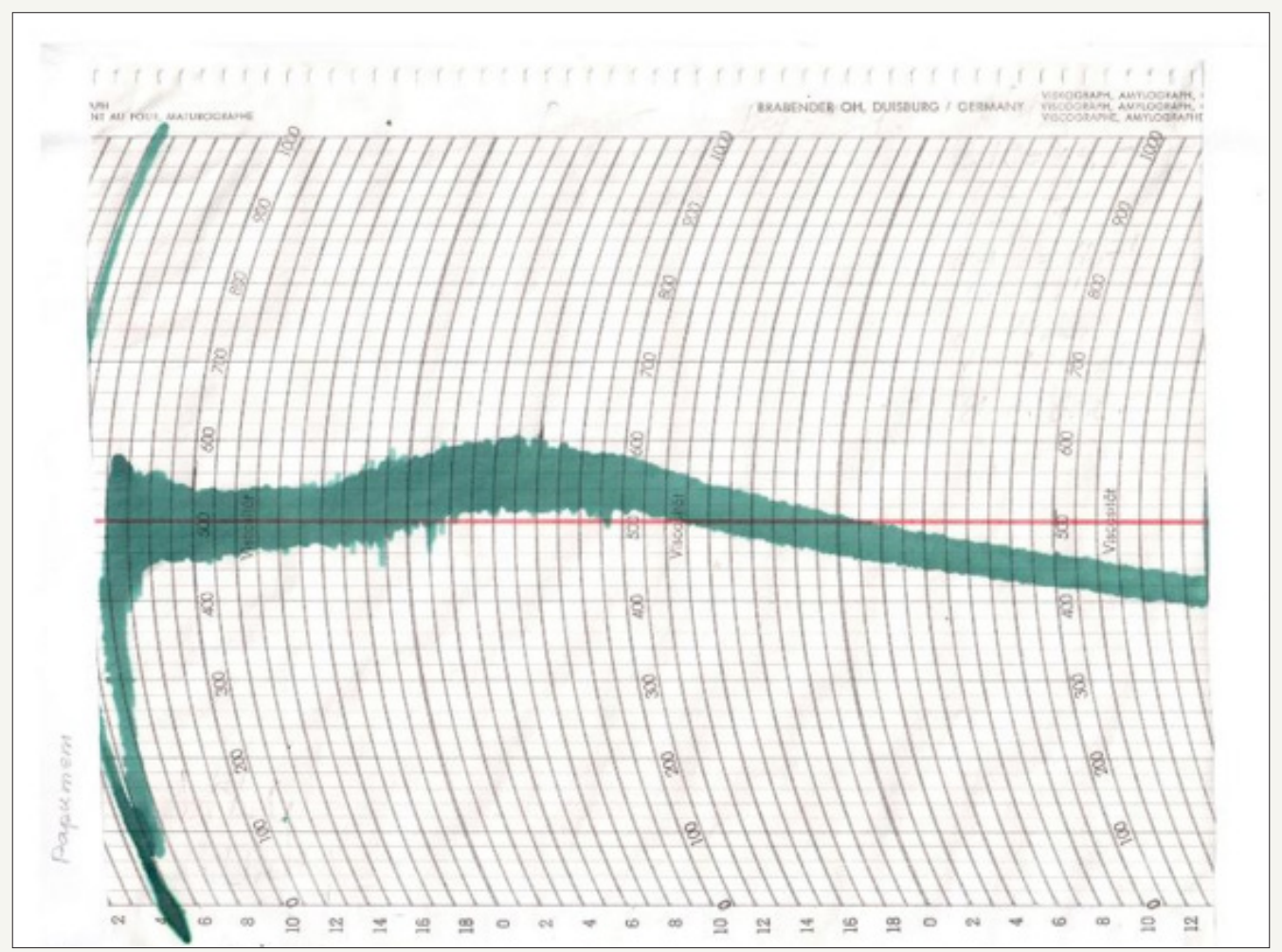

Figure 4: Farinogramm of the triticale cultivar Rarytet (2016).

The best low-stem lines of winter triticale have advantage in flour strength in comparison with the fodder and earlier created cultivars of baking destination. In 2014-2017, flour strength in the low-stem triticale was 190-353u.a., Amphidiploid 256-57u.a., Raritet-194u.a., winter wheat Podolyanka-157-262u.a. At a present stage of breeding, an important index of bakery qualities of triticale is balance of dough properties at high level. In the triticale with a weak gluten, elasticity of dough is very low: $39-52 \mathrm{~mm}$. The fodder triticale is more various by dough tensile strength: $37-82 \mathrm{~mm}$. Unlike the feed cultivars, Raritet has the dough balanced at the high level on elasticity and tensile strength (Figure 4).
On average for 2001-2011, these indexes were 71 and $74 \mathrm{~mm}$ and P/L equaled one. In 2014-2017, the cultivar Raritet formed the same elastic and tensile dough that provided obtaining bread without improvers with the volume of $627 \mathrm{ml}$ with the general bread making rating of 9 points. The HAD 7 line had unbalanced dough with elasticity 50 and tensile strength of $88 \mathrm{~mm}$. The lowstem triticale lines allocated from the combination Raritet/HAD 7 give dough with elasticity 72-96 and tensile strength of $68-89 \mathrm{~mm}$. The cultivars Timofey, Pudik and Yelan created with involvement of the best low-stem lines the elasticity- tensile strength was steadily high and averaged for 2014-2017 84-81mm, 81-77mm and 72- 
$77 \mathrm{~mm}$ respectively. In the same years, the P-L in Raritet was 7174 , in winter wheat Podolyanka-72-69mm. In triticale of fodder type (Amphidiploid 256, Pawo, Baltiko, Titan, etc.), the physical properties of dough are low: time of formations $1,30 \ldots 2,10 \mathrm{~min}$., resilience $0,50 \ldots 3,00 \mathrm{~min}$., resistance $2,00 \ldots 4,24 \mathrm{~min}$. , stability
$3,00 \ldots 5,40 \mathrm{~min}$. and softening varied from 156 to 220 u.f. The dough in such triticale is forming quickly but its stability is five times less and the valorimetric value is twice less in comparison with strong wheat and triticale of a baking type (Figure 5).

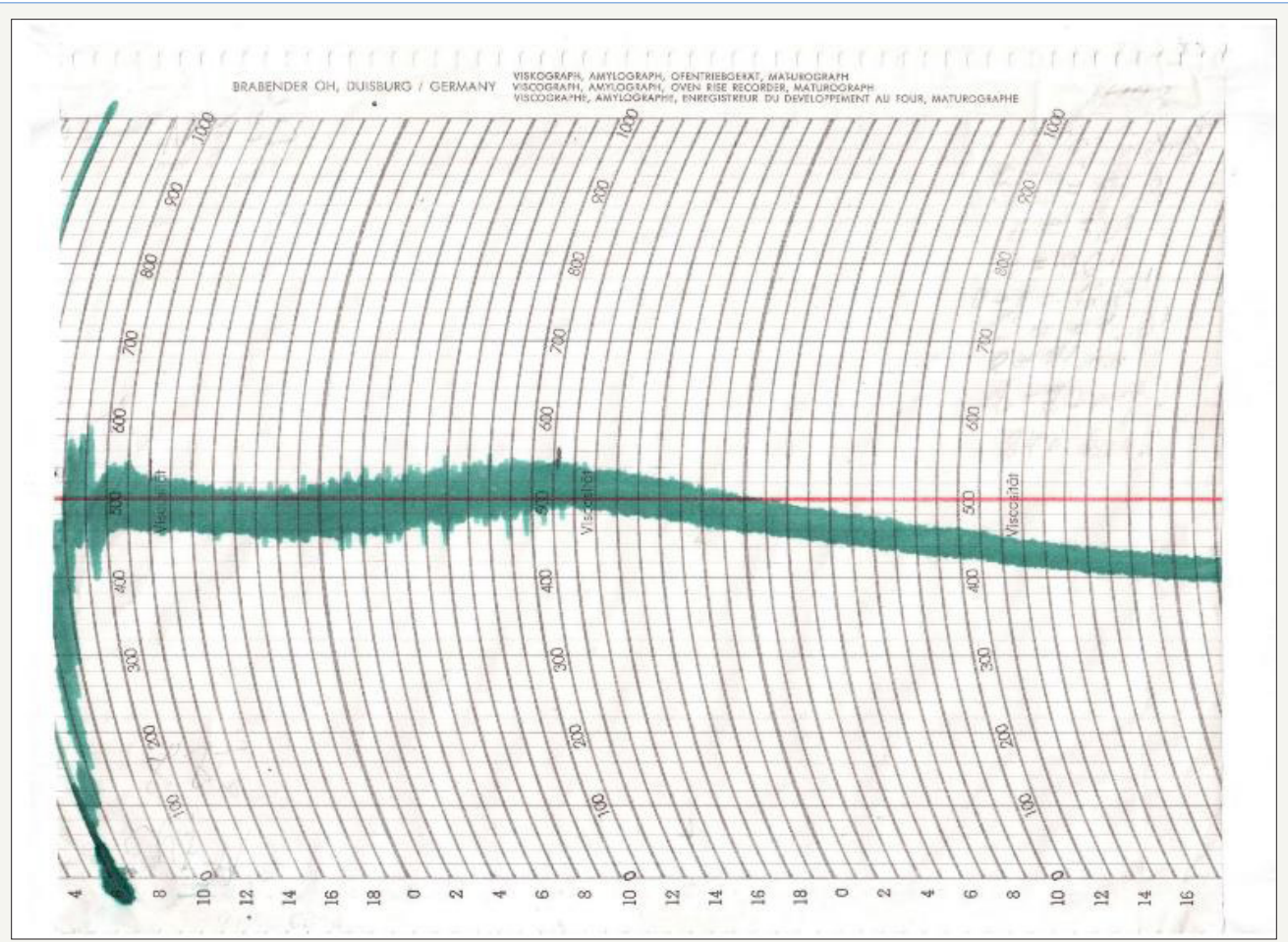

Figure 5: Farinogramm of the triticale cultivar Tymofii (2016).

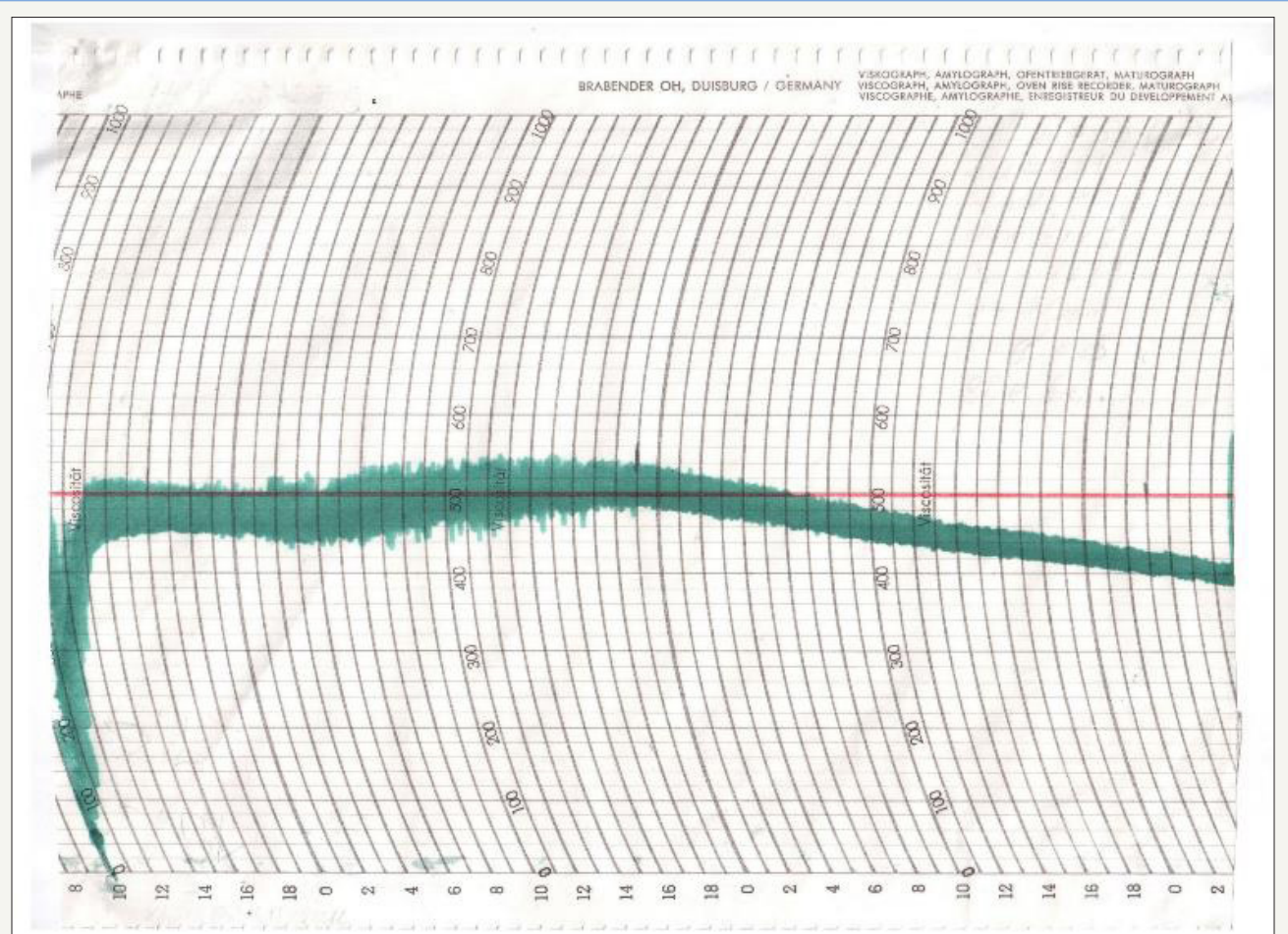

Figure 6: Farinogramm of the triticale cultivar Pudik (2016).

The best low-stem lines and cultivars of triticale give the dough elastic, steady against a batch and softening, tensile, with high gas- retaining ability which isn't inferior to the farinograms of valuable and strong wheats (Figure 4-7). So, in the lines HAD 69... 189, the 
cultivars Timofey, Pudik and Yelan, time of dough formation is of 2,8-3,5min., resilience-of $10,5-12,5 \mathrm{~min}$., resistance to a batch-of 13,4-15,7min., stability-10,5-17,2 min., dough liquefaction-5598u.f., valorimetric value 84-90e.v. The loaf volume at its production by wheat technology without improvers is at them of $610-880 \mathrm{ml}$ [9]. with the general bread making rating of 8,6-9,0 points (Figure $6 \& 7)$.

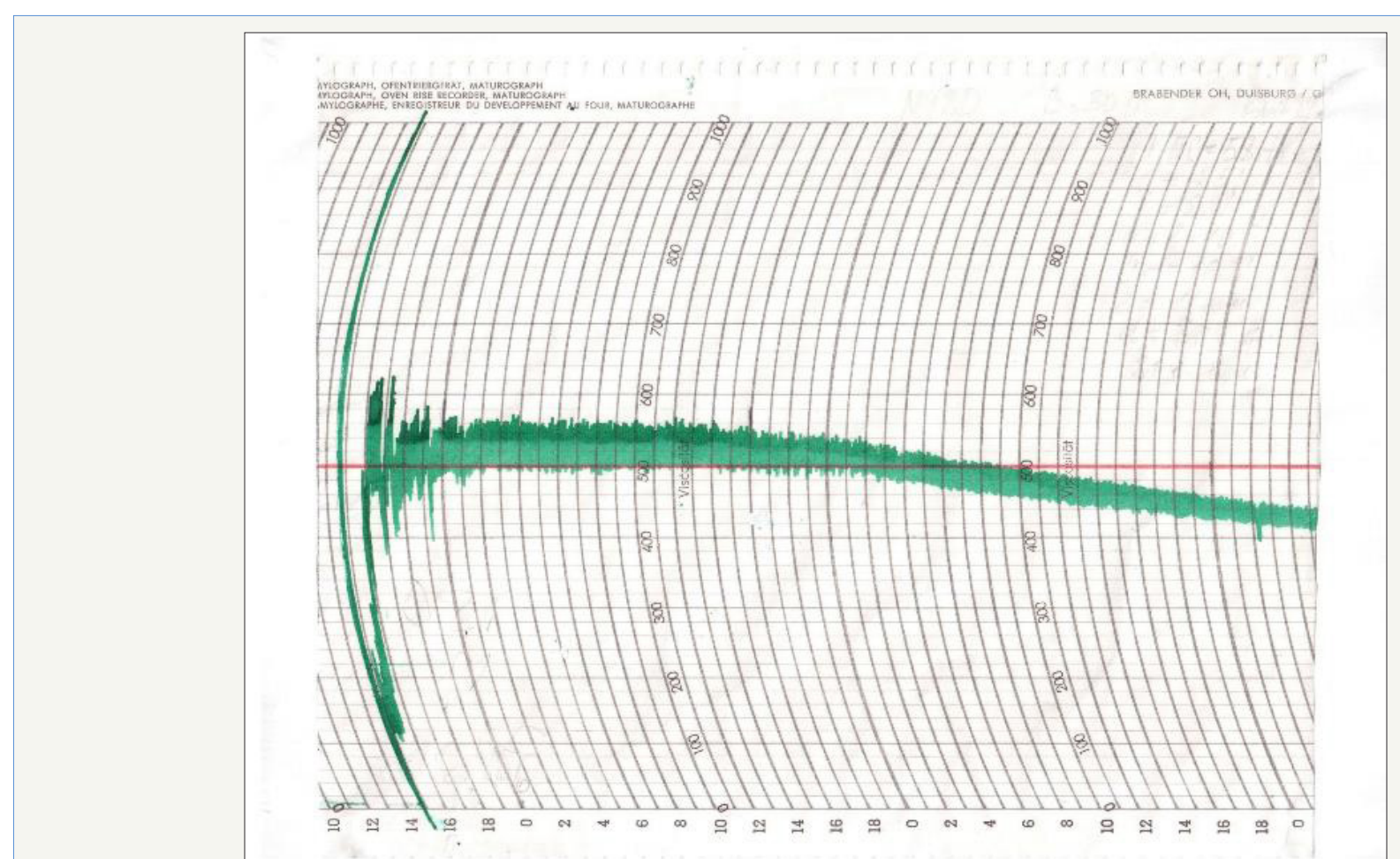

Figure 7: Farinogramm of the bread wheat cultivar Podolianka (2016).

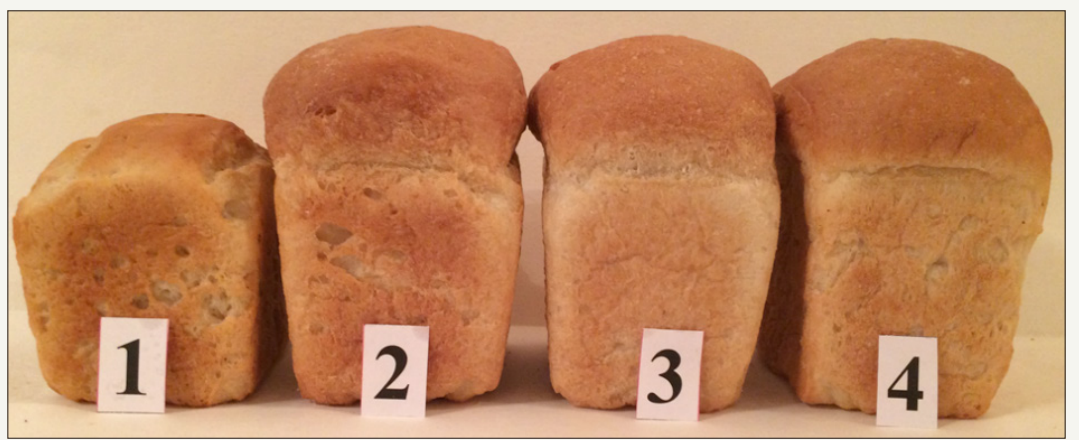

Figure 8: Bread of flour of varieties of triticale (1-3) and wheat (4)

1-Amfidyploid 256.

2-Rarytet.

3-Tymofii.

4-Podolianka (2017).

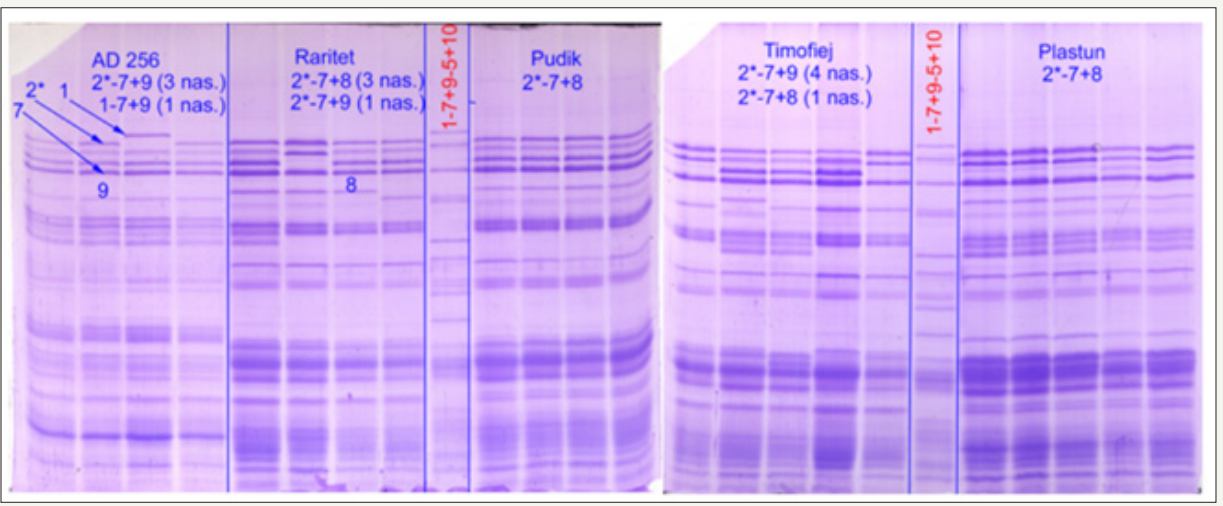

Figure 9: Electropherogramof glutenines of the triticale cultivars Amfidyploid 256, Rarytet, Pudik, Tymofii and Plastun. 
The highest quality of a gluten, dough and bread is revealed in the cultivars Pudik and Yelan having a subunit $2 *-7+8$. For further researches of the nature of quality of strongly connected wheat-rye gluten complex with use of the new approaches, seeds of the best low-stem cultivars are sent to the USA (J. Dubcovsky, UC Davis), Australia (R. Trethowan, The University of Sydney), Poland ( $\mathrm{H}$. Woś), Germany (K.J. Mueller, Cereal Breeding Research Darzau), Czech Republic (P. Martinek, Agricultural Research Institute Kromeriz, Ltd.), Russia (A.I. Grabovets, the Don ZNIISH), Mexico (H. J. Braun, CIMMYT) (Figure 8 \& 9).

\section{References}

1. Tritikale (2010) Materialyi mezhd. konf Rol tritikale v stabilizatsii i uvelichenii proizvodstva zerna i kormov/ Otv, red Grabovets AI-Rostovna-Donu, pp: 292s.

2. Tritikale (2017) Kultura XXI storIchchya. Tezi dop mIzhnn konf 4-6 lipnya 2017-HarkIv: TOV Nilan-LTD, p: 85.

3. Schipak GV (2016) SelektsIya geksaploYidnih tritikale na pIdvischennya adaptivnih vlastivostey, urozhaynostI ta yakostI zerna/ V kn: Osnovi upravlInnya produktsIynim protsesom polovih kultur. HarkIv, pp: 313373.
4. Schipak GV, Chernobab RA, Bosyuk EA, Metodyi (2017) Napravleniya i rezultatyi selektsii ozimyih geksaploidnyih tritikale $\mathrm{v}$ Institute rastenievodstva im. VYa Yureva NAAN/Tritikale-kultura XXI storIchchya. Tez dop mIzhn n konf HarkIv, p: 57-59.

5. Leonov O Yu, Panchenko IA, Sklyarevskiy KM (2011) MetodichnI rekomendatsIYi z otsInki yakostI zerna selektsIynogo materIalu/ta In HarkIv, p: 70s.

6. Schipak GV (1998) Rezultati selekts IYi tritikale dvoruchok//Selektslya I nasInnitstvo H. Vip 81: 38-45.

7. (2009) SposIb stvorennya sortlv ozimogo tritikale z pIdvischenimi tehnologIchnimi pokaznikami yakostI zerna. - Patent na korisnu model No. 44901.

8. Schipak GV, Tsupko Yu V, Schipak VG (2013) Hlebopekarnyie kachestva sortov ozimogo geksaploidnogo tritikale// Dokladyi Rashn p: 3-7.

9. Shevchenko VE, Pshenichnyiy AE (1976) Kachestvo zerna perspektivnogo tritikale Amfidiploid 206 v usloviyah Yugo-Vostoka TsChP//Tritikale. Problemyi i perspektivyi/Sb. nauch. rabot NIISH TsChP im. VV Dokuchaeva. Kamennaya Step 12(1): 70-77.
Creative Commons Attribution 4.0 International License

For possible submissions Click Here

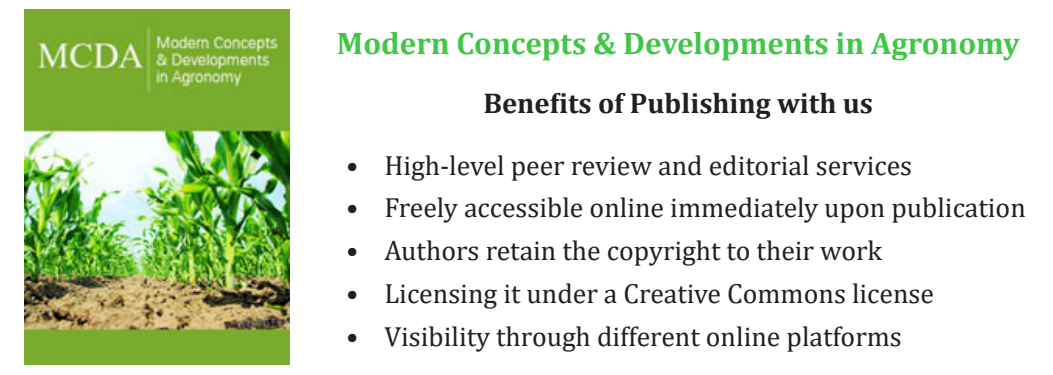

